\title{
PERANAN WARNA, VISKOSITAS, DAN SINERESIS TERHADAP PRODUK YOGHURT
}

\author{
The Role of Color, Viscosity, and Syneresis on Yogurt Products
}

\author{
Enjang Rohman, Shinta Maharani \\ Program Studi Pendidikan Teknologi Agroindustri, Fakultas Pendidikan Teknologi dan Kejuruan, \\ Universitas Pendidikan Indonesia, Bandung, Indonesia \\ E-mail: shinta.maharani@upi.edu
}

\begin{abstract}
ABSTRAK
Yoghurt plain merupakan yoghurt tanpa penambahan pemanis maupun flavor lain. Warna, viskositas, dan sineresis merupakan salah satu parameter karakteristik fisik yoghurt plain yang menjadi salah satu indikator karakteristik yoghurt secara keseluruhan. Warna putih kekuningan, putih terang sampai putih keruh yoghurt plain disebabkan oleh adanya pigmen karoten dan riboflavin pada basis susu. Viskositas yoghurt disebabkan oleh adanya koagulasi protein susu (kasein/misel) akibat penurunan $\mathrm{pH}$ karena produksi asam laktat selama proses fermentasi. Sineresis yoghurt merupakan fenomena pemisahan whey dari koagulan yoghurt karena penurunan kelarutan dan pengerutan partikel kasein. Bahan baku, proses pembuatan, dan penyimpanan yoghurt berpengaruh terhadap warna, viskositas, dan sineresis yoghurt plain. Penambahan total padatan terutama protein dan penggunaan stabiliser dapat dilakukan untuk memperbaiki viskositas dan sineresis yoghurt.
\end{abstract}

Kata kunci: sineresis, viskositas, warna, yoghurt plain

\begin{abstract}
Plain yogurt is yogurt without the addition of sweeteners or other flavors. Color, viscosity and syneresis are one of the parameters of physical characteristics of plain yogurt which is an indicator of the overall characteristics yogurt. Yellowish white color, bright-white to off-white color plain yogurt is caused by the presence of carotene and riboflavin pigments on the milk base. Yogurt viscosity is caused by coagulation of milk protein (casein / micelles) due to a decrease in pH due to lactic acid production during the fermentation process. Yogurt syneresis is a whey separation phenomenon from yogurt coagulants due to decreased solubility and contraction of casein particles. Raw materials, manufacturing processes, and storage of yogurt affect the color, viscosity, and syneresis of plain yogurt. Addition of total solids, especially proteins and use of stabilizers can be done to improve the viscosity and syneresis of yogurt.
\end{abstract}

Keywords: syneresis, viscosity, color, plain yogurt

\section{PENDAHULUAN}

Susu merupakan bahan pangan yang memiliki nilai gizi yang tinggi karena mengandung nutrisi yang sangat dibutuhkan oleh tubuh seperti protein dan lemak tinggi. Penyusun utama susu adalah air $(87,9 \%)$, protein $(3,5 \%)$, lemak $(3,5-4,2 \%)$, vitamin dan mineral $(0,85 \%)$. Namun, karena kandungan nutrisi yang tinggi dan juga kadar air yang tinggi pula, susu termasuk ke dalam bahan pangan yang sangat mudah rusak karena kondisinya sangat menguntungkan bagi mikroorganisme sebagai media pertumbuhan mikroba (Oktavia, dkk., 2016). Untuk menjaga kualitas susu agar tetap baik diperlukan teknologi pengolahan yang memungkinkan memperpanjang umur simpan susu, seperti teknologi fermentasi. 
Yoghurt merupakan salah satu contoh produk fermentasi susu yang telah banyak diketahui oleh masyarakat. Yoghurt adalah produk yang diperoleh dari fermentasi susu dan atau susu rekonstitusi dengan menggunakan bakteri Lactobacillus bulgaricus dan Streptococcus thermophillus dan atau bakteri asam laktat lain yang sesuai, dengan/atau tanpa penambahan bahan pangan lain dan bahan tambahan pangan yang diizinkan (SNI, 2009). Bahan baku yang umum digunakan dalam pembuatan yoghurt, dapat berupa susu penuh maupun susu tanpa lemak, susu kondensasi, maupun susu bubuk kering (Winarno, 2007).

Menurut Per-BPOM No 30 Tahun 2018 tentang Angka Konsumsi Pangan, angka konsumsi susu fermentasi termasuk yoghurt masyarakat Indonesia perharinya adalah sebanyak 155 gram/orang. Meskipun angka tersebut jauh lebih kecil dari angka konsumsi yoghurt negara lain, tetapi angka tersebut diprediksi akan meningkat tiap tahunnya. Data Kemenperin (2020), menunjukan angka impor yoghurt dari tahun 2012 sampai 2016 mengalami peningkatan sebanyak $225,98 \%$. Hal ini berarti beriringan dengan peningkatan kebutahan masyarakat Indonesia untuk mengonsumsi yoghurt.

Terdapat berbagai jenis yoghurt yang beredar dipasaran. Berdasarkan flavornya, yoghurt dibedakan menjadi yoghurt plain dan dengan perisa atau potongan buah (Corrieu, 2016). Yoghurt plain merupakan yoghurt tanpa penambahan pemanis maupun flavor lain, sehingga karakteristik yoghurt plain sangat tergantung pada kandungan asam laktat pada produk yang berpengaruh pada karakteristik fisik yoghurt (Corrieu, 2016).

Karakteristik fisik sangat penting dalam penentuan desain aliran proses produksi, quality control, penyimpanan, dan prediksi tekstur produk yoghurt (Shaker, dkk., 2010). Warna, viskositas, dan sineresis merupakan salah satu parameter karakteristik fisik yoghurt plain yang menjadi salah satu indikator yoghurt dan karakteristik yoghurt secara keseluruhan. Warna, viskositas dan sineresis juga berpengaruh terhadap tingkat kesukaan konsumen. Perubahan karakteristik fisik yoghurt dapat berpengaruh terhadap penolakan konsumen pada produk yoghurt, meskipun perubahan tersebut hanya berakibat pada penampilan yoghurt yang tidak menarik dan tidak mengakibatkan terjadinya perubahan kimia yang membahayakan kesehatan konsumen (Manab, 2008). Oleh karena itu, perlu adanya kajian mengenai peran warna, viskositas, dan sineresis terhadap yoghurt plain.

\section{PEMBAHASAN WARNA}

Pengujian warna yoghurt dapat dilakukan dengan uji kuantitatif dan uji sensori. Pengujian kuantitatif dilakukan dengan menggunakan alat Choromameter Konica Minolta CR-400 (Wibawanti \& Rinawidiastuti 2018) ataupun CR-300 (Frederiksen, 2003) yang menggunakan koordinat $\mathrm{CIE} \mathrm{L}^{*} \mathrm{a}^{*} \mathrm{~b}^{*}\left(\mathrm{~L}^{*}=\right.$ lightness, $\mathrm{a}^{*}=$ redness, dan $\mathrm{b}^{*}=$ yellowness $)$. Sementara pengujian sensori dilakukan untuk mengetahui penerimaan konsumen pada atribut warna yoghurt yang bisa dilakukan dengan uji hedonik, mutu hedonik, maupun uji skoring. Secara sensori plain yoghurt berwarna putih kekuningan, putih cerah sampai putih pucat (Yuceer \& Drake, 2013). Warna tersebut merupakan hasil refleksi cahaya oleh dispersi koloid dari kasein dan Ca-fosfat. Warna kuning yoghurt disebabkan oleh adanya dua pigmen kuning pada bahan baku susu yaitu karoten yang banyak terdapat pada lemak susu dan riboflavin yang banyak terkandung pada whey susu (Sugiyono, 2010). 
Jenis susu yang digunakan sebagai bahan dasar yoghurt berpengaruh terhadap warna yoghurt (Ginting \& Pasaribu, 2005). Yoghurt yang dihasilkan dari jenis susu berbeda menghasilkan warna yang berbeda tergantung dari warna susu bahan baku. Warna susu dipengaruhi oleh komposisi kimia dan sifat fisiknya, misalnya jumlah lemak, kekentalan susu, kandungan darah dan jenis pakan yang diberikan (Sugiyono, 2010). Pakan hijauan adalah sumber yang baik bagi beta karoten dimana warna kuning karoten akan terdapat pada lemak susu (Ginting \& Pasaribu, 2005). Kandungan riboflavin dan karoten pada susu full fat (270 $\mu \mathrm{g} / 100 \mathrm{~g}$ dan $21 \mu \mathrm{g} / 100 \mathrm{~g})$ lebih tinggi dari pada susu low fat $(250 \mu \mathrm{g} / 100 \mathrm{~g}$ dan 5,21 $\mu \mathrm{g} / 100 \mathrm{~g}$ ) (Tamime \& Robison, 2007), sehingga susu low-fat memiiki warna cenderung lebih putih karena kandungan lemaknya rendah (Ginting \& Pasribu, 2005). Ginting \& Pasribu (2005) dan Syiainah, dkk (2014), melaporkan yoghurt dari susu sapi segar memiliki nilai penerimaan konsumen lebih tinggi dari pada yoghurt dari susu skim, susu full krim dan susu kerbau segar.

Proses pembuatan yoghurt juga berpengaruh terhadap warna produk, misalnya perlakuan homogenisasi yang mereduksi ukuran globula lemak menyebabkan meningkatnya kemampuan susu untuk mereflesikan cahaya sehingga yoghurt menjadi lebih putih. Sementara heat-treatment bisa mereduksi pigmen kuning riboflavin sebanyak $<10 \%$ (Tamime \& Robison, 2007). Pada proses fermentasi, suhu inkubasi yoghurt berpengaruh terhadap warna yoghurt (Syiainah, dkk., 2014). Ginting \& Pasribu (2005), melaporkan bahwa yoghurt yang dibuat dari susu sapi full krim dengan starter Lactobacillus Bulgaricus dan Streptococcus Thermophilus yang diinkubasi pada suhu $44^{\circ} \mathrm{C}$ merupakan yoghurt dengan penilaian warna terbaik. Selain itu, pertumbuhan jenis mikroba atau kapang berpengaruh terhadap warna susu (Mirdhayati, dkk., 2010). Sunarlim, dkk. (2010), melaporkan bahwa yoghurt dengan starter campuran Streptococcus thermophiles dan Lactobacillus bulgaricus memiliki warna lebih putih dari pada yoghurt dengan starter Lactobacillus plantarum, maupun starter campuran antara Lactobacillus plantarum dan Streptococcus thermophiles, Lactobacillus plantarum dan Lactobacillus bulgaricus, juga starter campuran Lactobacillus plantarum, Streptococcus thermophiles, dan Lactobacillus bulgaricus.

Warna plain yoghurt sangat tidak stabil (Tamime \& Robison, 2007), karena Riboflavin sangat peka terhadap cahaya (Mirdhayati, dkk., 2010). Yoghurt yang terkena cahaya fluoresens putih selama 96 jam kadar riboflavinnya tereduksi sebanyak 0,3 $\mu \mathrm{g} / \mathrm{ml}$ (Tamime \& Robison, 2007). Frederiksen, dkk., (2003) yang mengamati perubahan warna plain yoghurt dengan koordinat $\mathrm{CIE} \mathrm{L}^{*} \mathrm{a}^{*} \mathrm{~b}^{*}$ yang disimpan pada kondisi terpapar cahaya flouresens dan gelap pada kemasan Polylaktida (PLA) dan Polystyrene (PS) melaporkan bahwa lightness $\left(\mathrm{CIE} \mathrm{L}^{*}\right.$ ) tidak mengalami perubahan. Perubahan redness (CIE $a^{*}$ ) dan yellowness (CIE $\left.b^{*}\right)$ ditunjukkan pada Grafik 1a dan b. Selama penyimpanan, redness yoghurt yang terpapar cahaya meningkat, kenaikan tertinggi terjadi pada yoghurt yang dikemas dalam PS. Redness semua yoghurt yang disimpan dalam kegelapan tidak berubah selama penyimpanan. Yellowness (Grafik 1b) yoghurt yang terpapar cahaya menurun secara signifikan, penurunannya lebih besar pada kemasan PS dari pada PLA, berbeda dengan yoghurt yang disimpan dalam kegelapan yang tidak ada perubahan yellowness. 


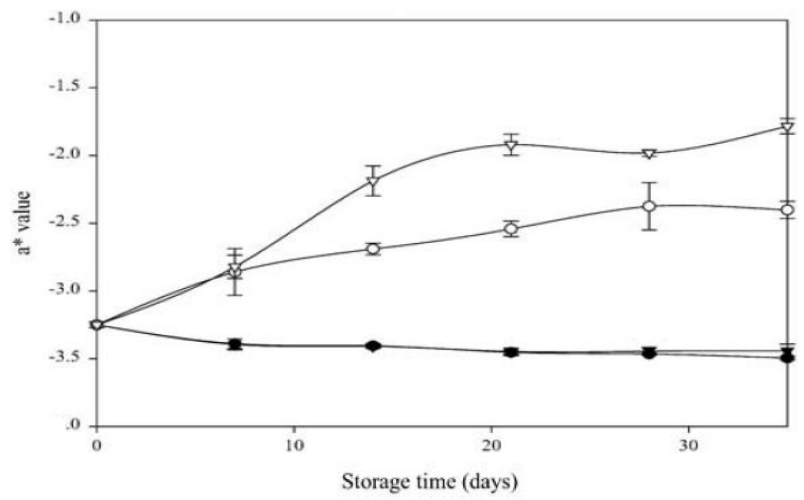

1(a)

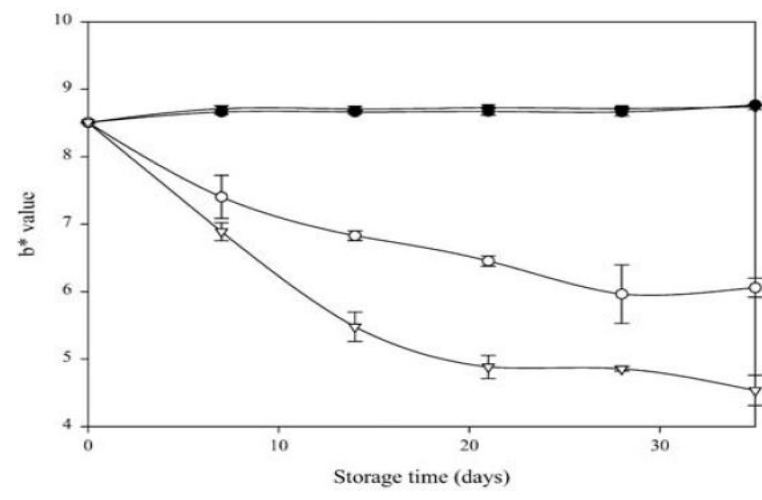

1 (b)

Grafik 1(a), (b). $a^{*}$ values (a) dan b* values (b). plain yoghurt kemasan PLA pada paparan cahaya fluoresens putih $(\bigcirc)$; plain yoghurt kemasan PLA pada keadaan gelap (๑); plain yoghurt kemasan PS pada paparan cahaya fluoresens putih $(\nabla)$; plain yoghurt kemasan PS pada keadaan gelap $(\boldsymbol{\nabla})$; standar deviasi $(\longrightarrow)$

Sumber: Frederiksen, dkk.(2003)

Frederiksen, dkk.(2003), menambahkan bahwa yoghurt yang disimpan pada papacan cahaya fluoresens putih yang dikemas dalam PLA mengalami reduksi riboflavin dan karoten yang lebih sedikit dari pada kemasan PS. Sementara pada penyimpanan gelap, konsentrasi riboflavin dan karoten tidak mengalami perubahan signifikan.

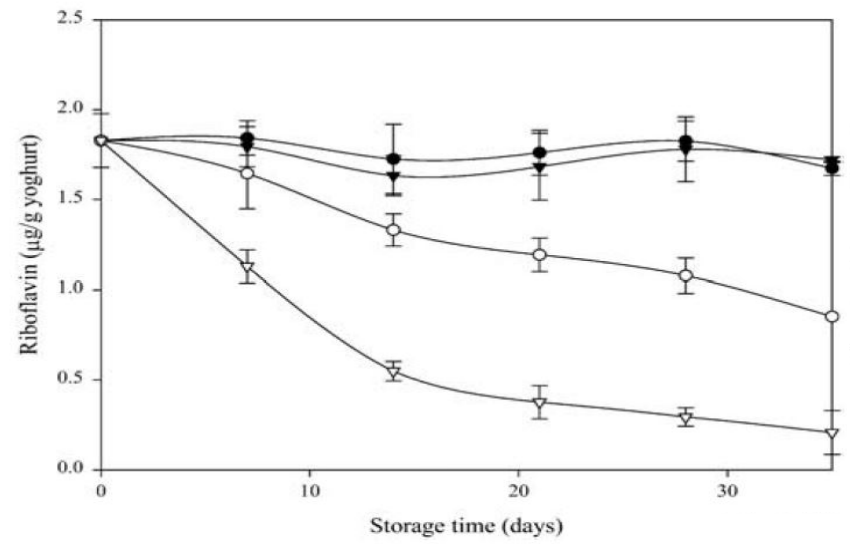

2(a)

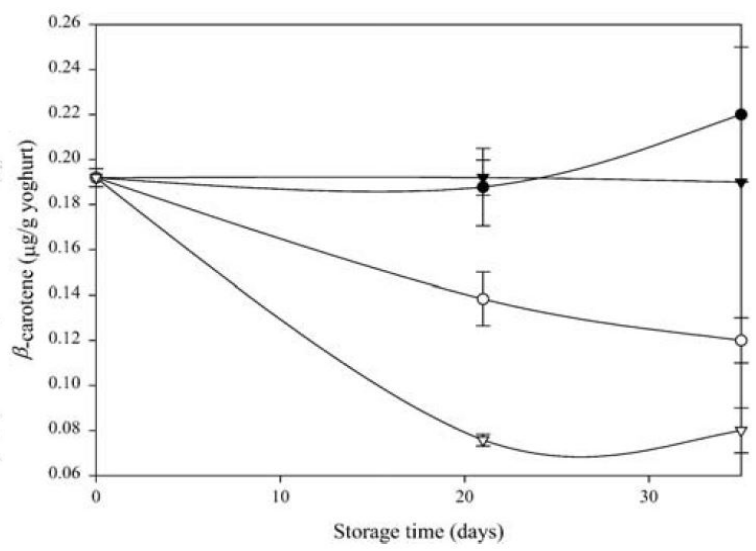

2(b)

Grafik 2(a), (b). riboflavin (a) dan karoten (b). plain yoghurt kemasan PLA pada paparan cahaya fluoresens putih (O); plain yoghurt kemasan PLA pada keadaan gelap (๑); plain yoghurt kemasan PS pada paparan cahaya fluoresens putih $(\nabla)$; plain yoghurt kemasan PS pada keadaan gelap $(\boldsymbol{\nabla})$; standar deviasi $(\longrightarrow)$

Sumber: Frederiksen, dkk.(2003) 


\section{VISKOSITAS}

Viskositas yoghurt menggambarkan sifat cairan yang mempunyai resistensi terhadap suatu aliran yang dapat memberikan peningkatan kekuatan untuk menahan gerakan relatif (Manab, 2008). Viskositas susu merupakan kontribusi dari keberadaan protein (kasein/misel) dan globula lemak yang terdapat pada susu tersebut (Sunarlimi , dkk., 2010). Fermentasi laktosa oleh starter yoghurt yang menghasilkan asam laktat dapat menurunkan $\mathrm{pH}$ susu. Pada $\mathrm{pH}$ dibawah 5,3 terjadi peningkatan viskositas karena menurunnya kelarutan kasein (Manab, 2008), pada pH 4,8-4,7 kasein akan terpresipitasi sempurna (Suprihana, 2012). Kasein yang terpresipitasi mempunyai sifat hidrofilik yang menyebabkan viskositas meningkat (Sunarlimi, dkk. 2010).

Dalam sebagian besar penelitian, pengukuran viskositas sering menggunakan alat viskometer rotasi seperti viskometer Brookfield (Leen \& Lucey, 2010). Pengukuran dilakukan dengan Spidel nomor 62 dengan kecepatan putaran $50 \mathrm{rpm}$. Nilai viskositas diambil apabila angka dial menunjukkan angka stabil atau angka yang sering muncul. Menurut Yucerr \& Drake, (2013), secara sensori viskositas dapat diukur secara oral dan non-oral. Viskositas oral dilakukan untuk mengukur ketegasan yoghurt. Yoghurt sebanyak satu sendok teh $( \pm 5$ $\mathrm{ml}$ ) dituangkan di atas permukaan yoghurt dan diamati seberapa cepat yoghurt dituang. Tingginya tingkat tuang dari sendok menunjukkan viskositas non-oral yang rendah. Sementara viskositas oral dilakukan untuk menilai "mouth fell" atau tingkat ketebalan yang dirasakan saat yoghurt dikonsumsi dan ditempatkan di mulut.

Keberaaan protein pada basis susu berbanding lurus dengan tingkat viskositas yoghurt, misalnya tanpa fortifikasi yoghurt susu kuda dan susu keledai mempunyai viskositas yang lebih rendah dari pada yoghurt susu domba atau rusa (Tamime \& Robinson,2007). Sementara Sunarlim, dkk. (2010), melaporkan bahwa kadar lemak pada basis susu juga berpengaruh terhadap viskositas selama masa inkubasi yoghurt. Grafik 3. menunjukan peningkatan viskositas pada kadar lemak yang lebih tinggi, hal ini disebabkan oleh peningkatan total padatan susu yang secara signifikan berpengaruh pada kekentalan susu (Shaker,dkk., 2010). Kadar protein dan lemak dari susu berbagai spesies dapat dilihat pada Tabel 1.

Tabel 1. Kandungan susu berbagai spesies

\begin{tabular}{cccc}
\hline Spesies & Fat $\mathbf{( g / 1 0 0 g )}$ & Protein $\mathbf{( g / 1 0 0 g )}$ & Laktosa $\mathbf{( g / 1 0 0 g )}$ \\
\hline Keledai & 2,5 & 2,0 & 6,0 \\
Banteng & 8,0 & 4,2 & 4,9 \\
Unta & 4,2 & 3,7 & 4,1 \\
Sapi & 3,9 & 3,3 & 4,7 \\
Kambing & 4,5 & 3,3 & 4,6 \\
Kuda & 1,9 & 2,6 & 6,2 \\
Rusa kutub & 22,5 & 10,3 & 2,5 \\
Kambing & 7,5 & 5,6 & 4,4 \\
\hline
\end{tabular}

Sumber (Tamime \& Robinson,2007) 


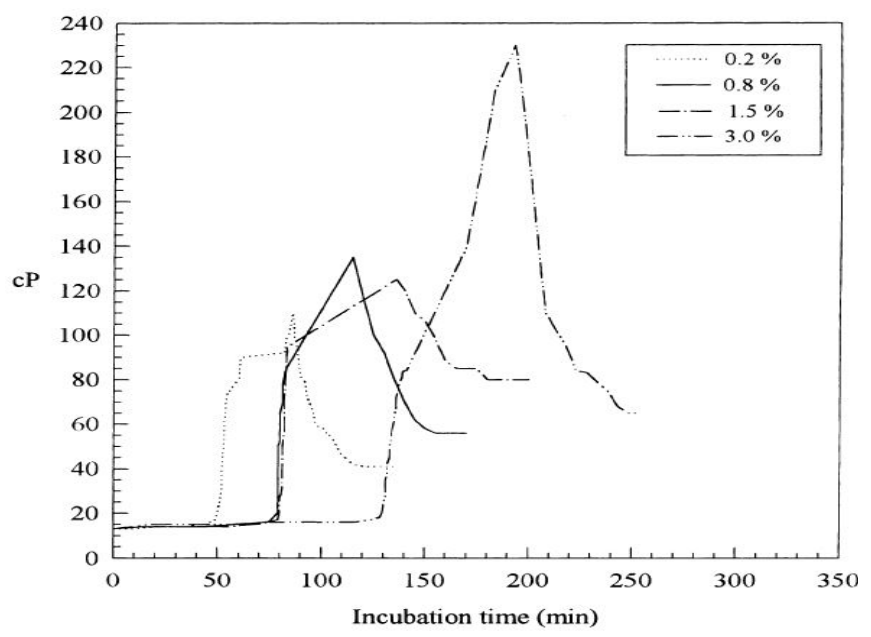

Grafik 3. Pengaruh kadar lemak terhadap viskositas selama masa inkubasi yoghurt Sumber: Shaker,dkk., (2010)

Untuk mendapatkan tingkat viskositas yang dihendaki, banyak industri yoghurt yang melakukan fortifikasi fraksi bahan lain pada saat standarisasi bahan baku. Penambahan tersebut diantara nya: (1) Milk powder, Skimmed milk powder (SMP) merupakan yang lebih populer digunakan dengan rekomendasi penambahan 3-4\%; (2) Buttermilk powder (BMP), digunakan hingga 50\% untuk menggantikan SMP pada yoghurt low-fat; (3) Whey powder (WP) dan whey protein concentrates (WPC), yoghurt bisa dibuat dengan kombinasi penggunaan SMP dan WP $(75: 25)$ dan penambahan 1\% WPC dapat meningkatkan viskositas yoghurt low-fat, dan mereduksi biaya produksi sebanyak $50 \%$; (4) casein powder, mengadung kasein dan bahan lain yang bisa meningkatkan protein dan viskositas yoghurt (Tamime \& Robinson,2007), perbadingan komposisi berbagai powder dapat dilihat pada Tabel 3; (5) Stabliser, berupa hidrokolid yang bisa meningkatkan dan menjaga keseragaman viskositas yoghurt (Djali, dkk., 2018). Beberapa penelitian tentang kajian penambahan bahan untuk memperbaiki tingkat viskositas yoghurt dapat dilihat pada Tabel 2.

Selain dari bahan pembuatan yoghurt, proses pembuatan juga berpengaruh terhadap viskositas yoghurt. Adam (2010), menyebutkan bahwa yoghurt yang diproduksi pada suhu $42^{\circ} \mathrm{C}$ memiliki nilai viskositas yang lebih tinggi dari pada yoghurt yang diproduksi pada suhu $30{ }^{\circ} \mathrm{C}$. Sementara Penna, dkk. (2006), mengurutkan perlakuan heat-treatment yang memberikan nilai viskositas yoghurt tertinggi adalah perlakuan pemanasan pada tong $\left(85^{\circ} \mathrm{C} /\right.$ 10-40 menit) > HTST $\left(98^{\circ} \mathrm{C} /\right.$ 0,5-1,87 menit $)>$ UHT $\left(140{ }^{\circ} \mathrm{C} / 2-8 \mathrm{~s}\right)>$ susu yang tidak dipanaskan. Perlakuan panas akan menyebabkan kasein mengalami aggresi, disagregasi, menyebabkan cross-linking misalnya dengan isopeptida yang bisa menyebabkan peningkatan ukuran misel dan juga menyebabkan denaturasi whey protein yang juga bisa meningkatkan ukuran misel (Tamime \& Robinson, 2007). Penggunaan starter yang menghasilkan eksopolisakarida juga bisa meningkatkan viskositas yoghurt (Tamime \& Robinson, 2007). Caspian Sea Yoghurt memiliki viskositas yang lebih tinggi karena Lactococcus (L) lactis ssp. Cremoris menghasilkan eksopolisakarida ekstraseluler (Uchida, dkk. 2009). Penggunaan Caspian Sea Yoghurt sebagai inokulum juga lebih mudah diaplikasikan di Indonesia karena inkubasi dapat dilakukan pada suhu $30^{\circ} \mathrm{C}$ tanpa menggunakan inkubator (Maharani dkk., 2019). 
Tabel 2. Literatur tentang fostifikasi untuk memperbaiki tingkat viskositas yoghurt

\begin{tabular}{|c|c|c|}
\hline Sumber & Bahan yang ditambahkan & Keterangan \\
\hline Manab (2008) & $\begin{array}{l}\text { - Susu skim } \\
\text { - Sukrosa }\end{array}$ & $\begin{array}{l}\text { Penambahan susu Skim } 10 \% \\
\text { viskositasnya lebih tinggi }(0,7860 \\
\text { CP) dari pada Penambahan Skim } \\
10 \%+\text { Sukrosa } 5 \%(0,5895 \mathrm{cP})\end{array}$ \\
\hline Lee \& Lucey (2010) & $\begin{array}{l}\text { Stabiliser seperti pektin dan } \\
\text { gelatin }\end{array}$ & $\begin{array}{l}\text { - Penggunaan stabilisator dapat } \\
\text { meningkatkan dan memberikan } \\
\text { viskositas yang lebih stabil } \\
\text { - Penambahan berlebihan dapat } \\
\text { menghasilkan yoghurt kenyal } \\
\text { seperti jelly } \\
\text { - Di beberapa negara seperti } \\
\text { Belanda dan Perancis } \\
\text { penambahan stabilisator pada } \\
\text { plain yoghurt merupakan } \\
\text { tindakan illegal }\end{array}$ \\
\hline $\begin{array}{l}\text { Gassem \& Frank } \\
(2000)\end{array}$ & $\begin{array}{l}\text { Proteolytic Enzim } \\
\text { - Pseudomoas Protease A } \\
\text { (PSA) } \\
\text { - Pseudomonas Protease B } \\
\text { (PSB) } \\
\text { - Plasmin(PS) }\end{array}$ & $\begin{array}{l}\text { Pada penyimpanan hari pertama, } \\
\text { Penambahan PSA dan PSB } \\
\text { sebanyak } 200 \mathrm{mg} / \mathrm{L} \text { memberikan } \\
\text { nilai viskositas lebih tinggi, masing } \\
\text { masing } \pm 3800 \text { dan } \pm 4000 \mathrm{cPs} \text { dari } \\
\text { pada kontrol ( } \pm 3000 \mathrm{cPs} \text { ) tetapi } \\
\text { tidak pada pada penambahan } 5 \mathrm{mg} \\
\mathrm{PS}( \pm 2900 \mathrm{cPs})\end{array}$ \\
\hline Hematyar, dkk., (2012 & ) Gum Xanthan & $\begin{array}{l}\text { Penambahan gum xanthan dengan } \\
\text { konsentrasi } 0,005 \% \text { dan } 0,01 \% \\
\text { dapat meningkatkan viskositas } \\
\text { yoghurt lemak utuh dan tidak } \\
\text { memengaruhi flavor yoghurt }\end{array}$ \\
\hline Djali, dkk. (2018) & $\begin{array}{l}\text { - Whey protein Concentrate } \\
\text { (WPC) } \\
\text { - Stabiliser (Gum Xanthan) }\end{array}$ & $\begin{array}{l}\text { Penambahan WPC dan kombinasi } \\
\text { WPC-gum xanthan mampu } \\
\text { meningkatkan viskositas lebih } \\
\text { tinggi dibandingkan yoghurt kontrol } \\
\text { dengan lemak utuh. }\end{array}$ \\
\hline Shana, dkk., (2007) & b-glucan hydrocolloidal & $\begin{array}{l}\text { Penambahan } 0,25 \%, 0,5 \% \text {, dan } \\
1 \% \text { g-glukan menghasilkan } \\
\text { viskositas pada hari pertama } \\
\text { masing masing } \pm 2.950,3.300 \text {, dan } \\
4000 \text { yang lebih tinggi dari kontrol } \\
( \pm 3800 \mathrm{cP})\end{array}$ \\
\hline $\begin{array}{l}\text { Soukoulis \& Tzia } \\
(2008)\end{array}$ & $\begin{array}{l}\text { Hidrokoloid: } \\
\text { - Xanthan } \\
\text { - Guar gum } \\
\text { Anionic : } \\
\text { CMC }\end{array}$ & $\begin{array}{l}\text { Viskositas secara signifikan } \\
\text { meningkat dengan penambahan } \\
\text { hidrokoloid. Campuran yang } \\
\text { mengandung xanthan memiliki } \\
\text { viskositas tertinggi dan yang } \\
\text { terendah mengandung CMC. }\end{array}$ \\
\hline
\end{tabular}


Secara fisik, stirred dan drink yoghurt memiliki tingkat viskositas yang lebih rendah dari pada set yoghurt (Adam, 2010). Proses mixing pada stirred dan drink yoghurt dapat mereduksi viskositas (Lee \& Lucey, 2010), begitupun proses whipping pada drink yoghurt yang menyebabkan nilai viskositas drink yoghurt (500 cPs) lebih kecil dari pada strirred yoghurt (1500 CPs)(PCM, 2015). Meskipun setelah proses mixing ataupun whipping terjadi proses "rebodying" yaitu pemulihan struktur, tetapi struktur gel yang terpulihkan hanya $30 \%$ bahkan setelah penyimpanan 20 jam (Lee \& Lucey, 2010). Pernyataan ini selaras dengan pernyataan Sahan, dkk (2007) yang melaporkan bahwa terjadi peningkatan viskositas setelah 15 hari penyimpanan dikarenakan penataan ulang protein dan penambahan bglucan dapat meningkatkan kecepatan penataan ulang sebesar 2,5 kali.

Pada produk akhir, proses penyimpanan pada suhu $<10^{\circ} \mathrm{C}$ dapat mempertahankan viskositas yoghurt terlebih jika ada penambahan stabiliser. Apabila diatas suhu tersebut bisa terjadi penurunan viskositas, karena aktivitas starter yang terus berlanjut menghidrolisis protein ataupun karena aktivitas mikroba kontaminan. Proses transfortasi juga dapat menurunkan viskositas yoghurt karena adanya kocokan pada produk (Tamime \& Robinson, 2007).

\section{SINERESIS}

Sineresis pada yoghurt merupakan fenomena pemisahan whey dari koagulan yoghurt (Tamime \& Robinson, 2007). Sineresis terjadi karena adanya penyusutan struktur tiga dimensi dari jaringan protein yang menyebabkan turunnya kekuatan ikatan whey protein sehingga terpisah dari yoghurt (Djali, 2018). Manab (2008), menjelaskan bahwa terjadinya sineresis kemungkinan disebabkan oleh perubahan kelarutan kasein dan pengkerutan partikel kasein. Seperti yang telah dijelaskan, pada $\mathrm{pH}$ yang leibih rendah kelarutan protein dan kasein akan berkurang yang menyebabkan terjadinya interaksi protein-protein yang lebih banyak dan interaksi protein-air lebih rendah. Rendahnya interaksi protein-air akan mengakibatkan terjadinya presipitasi sehingga jaringan protein mempunyai kecenderungan untuk melepas air. Peningkatan interaksi protein-protein dan menurunnya interaksi proteinair menyebabkan pengeruktan atau kontaksi gel protein yang memacu pembentukan curd bersamaan dengan terjadinya pemisahan whey. Apabila building block dari jaringan protein mengkerut, maka semua jaringan akan mengkerut secara proporsional sehingga kemampuan protein untuk mengikat atau memerangkap air bisa hilang. Terjadinya sineresis selama penyimpanan produk yoghurt merupakan cacat kenampakan yang penting diperhatikan oleh produsen yoghurt (Sahan, 2007).

Banyak penelitian yang mengukur sineresis yoghurt melalui proses sentrifugasi berkecepatan tinggi dan uji drainase (Lee dan Lucey, 2010). Pengukuran sineresis menggunakan alat sentrifus bertujuan untuk mengukur resistensi gel untuk menampung air akibat adanya gaya eksternal (Lee dan Lucey, 2010), sebanyak $15 \mathrm{ml}$ sampel yoghurt disentrifugasi pada kecepatan $1535 \mathrm{rpm}$ selama 20 menit. Perbandingan cairan yang terpisah dengan berat awal sampel dicatat sebagai tingkat sineresis (Sari, dkk., 2019). Sementara metode drainase bertujuan untuk mengukur sineresis spontan yang merupakan pemisahan whey akibat jaringan yang tidak stabil dan tanpa pengaruh kekuatan eksternal (Lee dan Lucey, 2010). Sebanyak 25 gram sampel yoghurt ditempatkan di atas kertas saring Whatman no. 4, volume whey yang terpisah diukur setelah 15 menit pada suhu ruang. Indeks sineresis dinyatakan sebagai persentase whey yang terpisah terhadap berat awal gel (Djali, dkk., 2018). 
Tingkat sineresis dipengaruhi oleh metode fortifikasi yang digunakan dan tingkat kasein (Tamime \& Robinson, 2007). Penambahan total padatan terutama protein dan penggunaan stabiliser dapat mengurasi tingkat sineresis yoghurt (Lee dan Lucey, 2010). Penambahan skimmed milk powder (SMP), butter milk powder (BMP), whey powder (WP), whey protein concentrates (WPC), dan casein powder diketahui dapat mengurangi tingkat sineresis, dengan tingkat efektifitasnya adalah WPC $>$ Na-caseinate $>$ SMP $>$ BMP. Penambahan hingga $1 \%$ casein powder dapat mengurangi sineresis sebesar $26,5 \pm 30 \%$ dalam yoghurt yang dibuat menggunakan galur S. Termofilus (Tamime \& Robinson, 2007). Stabiliser berupa hidrokoloid seperti gelatin, pektin, CMC dan gum dapat ditambahkan untuk menurunkan tingkat sineresis dan menjaga kestabilan gel sehingga dapat menekan tingkat sineresis selama penyimpanan (Soukoulis \& Tzia, 2008). Sementara Djali, dkk. (2018), melaporkan bahwa yoghurt yang dibuat dengan susu skim dengan penambahan WPC, SMP, dan Gum Xantan sebagai stabiliser berbagai konsentarsi memberikan indeks sineresis selama penyimpanan yang lebih kecil dari pada yoghurt susu segar, dengan tingkat sineresis terendah adalah yoghurt yang dengan bahan baku susu skim + SMP 3\% + WPC $1,25 \%$.

\section{KESIMPULAN}

Plain yoghurt berwarna putih kekuningan, putih cerah sampai putih pucat. Warna tersebut merupakan hasil refleksi cahaya oleh dispersi koloid dari kasein dan Ca-fosfat dan adanya pigmen warna karoten dan riboflavin pada basis susu. Viskositas yoghurt disebabkan oleh adanya koagulasi protein susu (kasein/misel) akibat penurunan $\mathrm{pH}$ karena produksi asam laktat selama proses fermentasi. Sineresis yoghurt merupakan fenomena pemisahan whey dari koagulan yoghurt karena penurunan kelarutan dan pengerutan partikel kasein. Bahan baku, proses pembuatan, dan penyimpanan yoghurt berpengaruh terhadap warna, viskositas, dan sineresis yoghurt plain. Penambahan total padatan terutama protein dan penggunaan stabiliser dapat dilakukan untuk memperbaiki viskositas dan sineresis yoghurt.

\section{DAFTAR PUSTAKA}

Adam, I. M. (2010). Effect Of Manufacturing Methods on The Quality of Yoghurt. Sudan : University Of Khartoum.

Badan Pengawas Obat dan Makanan. (2018). Peraturan Badan Pengawas Obat dan Makanan Nomor 30 Tahun 2018 tentang Angka Konsumsi Pangan.

Corrieu, G. (2016). Encyclopedia Of Food And Healt. Paris: Agroparistech.

Djali, M., Huda, S., \& Andriani, L. (2018). Karakteristik Fisikokimia Yogurt Tanpa Lemak dengan Penambahan Whey Protein Concentrate Dan Gum Xanthan . Agritech, 38 (2):178-186.

Frederiksen, C. S., Poll, V. K., \& Becker, E. M. (2003). Light-Induced Quality Changes In Plain Yoghurt Packed In Polylactate And Polystyrene. Eur Food Res Technol, 61-69.

Gassem, M. A., \& Frank, J. F. (2000). Physical Properties Of Yogurt Made From Milk Treated With Proteolytic Enzymes. J Dairy Sci 74, 1503-1511.

Ginting, N., \& Pasaribu, E. (2005). Pengaruh Temperatur Dalam Pembuatan Yoghurt Dari Berbagai Jenis Susu Dengan Menggunakan Lactobacillus Bulgaricus Dan Streptococcus Thermophilus. Jurnal Agribisnis Peternakan, 1 (2):73-77. 
Hematya, N., Samarin, A. M., \& H. Poorazarang, A. H. (2012). Effect Of Gums On Yogurt Characteristics. World Applied Sciences Journal, 20(5): 661-665.

Karagül-Yüceer, Y., \& Drake, M. (2013). Sensory Analysis Of Yogurt. Manufacturing Yogurt And Fermented Milks, 353-367.

Kementrian Perindustrian Republik Indonesia . (2020). Perkembangan Impor Kelompok Olahan Produk Susu Lainnya. Dipetik Maret 10, 2020, dari kemenperin.co.id: https://kemenperin.go.id/statistik/barang.php?ekspor=\&kode=202010043

Kepala Badan Pengawas Obat dan Makanan. Peraturan Kepala Badan Pengawas Obat dan Makanan Republik Indinesia Nomor 21 Tahun 2016 Tentang Kategori Pangan.

Lee, W. J., \& Lucey, J. A. (2010). Formation And Physical Properties Of Yogurt. Asian-Aust. J. Anim. Sci., 1127-1136.

ADDIN Mendeley Bibliography CSL_BIBLIOGRAPHY Maharani, S., Rahayu, A., Azizah, D. N., Rahayu, D. L., Pendidikan, U., \& Bandung, I. (2019). Perbandingan Penambahan Ekstrak Teh pada Karakteristik Kimia Caspian Sea Yoghurt. Jurnal Ilmu Pangan Dan Hasil Pertanian, 3(2), 138-149.

Manab, A. (2008). Kajian Sifat Fisik Yogurt Selama Penyimpanan Pada Suhu $4^{\circ} \mathrm{C}$. Jurnal IImu Dan Teknologi Hasil Ternak, 3(1): 52-58.

Mirdhayati, I., Handoko, J., \& Putra, K. U. (2010). Mufu Susu Segar Di Upt Ruminansia Besar Dinas Peternakan Kabupaten Kampar Provinsi Riau. Jumal Peternakan Vol 5 No 1, 14-21.

Oktavia, H., Radiati, L. E., \& Rosyidi, D. (2016). Pengaruh Penambahan Kultur Tunggal Dan Campuran Dengan Lama Inkubasi Pada Suhu Ruang Terhadap Kadar Ph, Keasaman, Viskositas Dan Sineresis Pada Set Yogurt. Jurnal Gizi Indonesia, 65-71.

PCM (2015). Set, Stirred, Drinking Yogurt - PLF*. diakses di: https://www.pcm.eu

Penna, A. L., Converti, A., \& Oliveira, M. N. (2006). Simultaneous Effects Of Total Solids Content, Milk Base, Heat Treatment Temperature And Sample Temperature On The Rheological Properties Of Plain Stirred Yogurt. Biotechnol, 44 (4): 515-518.

Sahana, N., Yasarb, K., \& Hayalogluc, A. (2007). Physical, Chemical And Flavour Quality Of Non-Fat Yogurt As Affected By A B-Glucan Hydrocolloidal Composite During Storage. Food Hydrocolloids, 22: 1291-1297.

Sari, D., Purwadi, \& Thohari, I. (2019). Upaya Peningkatan Kualitas Yoghurt Set Dengan Penambahan Pati Kimpul (Xanthosoma Sagittifolium). Jurnal IImu-IImu Peternakan, 131-142.

Shaker, R., Jumah, R., \& Abu-Jdayil, B. (2010). Rheological Properties Of Plain Yogurt During Coagulation Process: Impact Of Fat Content And Preheat Treatment Of Milk. Journal Of Food Engineering, 44:175-180.

Soukoulis, C., \& Tzia, C. (2008). Impact Of The Acidification Process, Hydrocolloids And Protein Fortifiers On The Physical And Sensory Properties Of Frozen Yogurt. International Journal Of Dairy Technology, 170-177.

Standar Nasional Indonesia. (2009). 2981 Yogurt.

Sugiyono. (2010). IImu Bahan Pangan. Yogyakarta: Universitas Negeri Yogyakarta.

Sunarlim, R., Setiyanto, H., \& Poeloengan, M. (2010). Pengaruh Kombinasi Starter Bakteri Lactobacillus Bulgaricus, Streptococcus Thermophilus Dan Lactobacillus Plantarum Terhadap Sifat Mutu Susu Fermentasi. Seminar Nasional Teknologi Peternakan Dan Veteriner, 270-278.

Suprihana. (2012). Pengaruh Lama Penundaan Dan Suhu Inkubasi Terhadap Sifat Fisik Dan Kimia Yoghurt Dari Susu Sapi Kadaluwarsa. Agrika, Volume 6, 94-102.

Syainah, E., Novita, S., \& Yanti, R. (2014). Kajian Pembuatan Yoghurt Dari Berbagai Jenis Susu Dan Inkubasi Yang Berbeda Terhadap Mutu Dan Daya Terima. Jurnal Skala Kesehatan 5 (1). 
Tamime, A. Y., \& Robinson, R. K. (2007). Tamime And Robinson Yoghurt Science And Techology Third Edition. Coventry, West Midlands, England: Tj International Limited.

Uchida, Kenji, Keiko Akashi, Hidemasa Motoshima, Tadasu Urashima, Ikichi Arai, and Tadao Saito. 2009. "Microbiota Analysis of Caspian Sea Yogurt, a Ropy Fermented Milk Circulated in Japan." Animal Science Journa, 80 (2): 187-192.

Wibawanti, J. M., \& Rinawidiastuti. (2018). Sifat Fisik Dan Organoleptik Yogurt Drink Susu Kambing Dengan Penambahan Ekstrak Kulit Manggis (Garcinia Mangostana L.). Jurnal IImu Dan Teknologi Hasil Ternak, 27-37.

Winarno, F. (2007). Susu dan Produk Fermentasinya. Bogor: M-Brio Press. 